\title{
Credit Risk and Lottery-type Stocks: Evidence from Taiwan
}

\author{
Lu Chia-Wu
}

Department of Finance and Cooperative Management, National Taipei University, Taiwan

Copyright $\bigcirc 2016$ by authors, all rights reserved. Authors agree that this article remains permanently open access under the terms of the Creative Commons Attribution License 4.0 International License

\begin{abstract}
This study explores the effect of credit risk on the lottery-type stocks with Taiwan's data during the sample period 2001 to 2010 . The lottery-type stocks are identified as the criteria referring to Kumar [1], which have characters of lower stock price, higher idiosyncratic volatility, and higher idiosyncratic skewness. Refer to Merton [2] and Vassalou \& Xing [3], a firm's credit risk is proxied by the DLI (default likelihood indicators). The main results show that the lottery-type stocks have higher default probabilities, smaller firm sizes and higher $\mathrm{B} / \mathrm{M}$ (book to market) ratio comparing to the non-lottery type ones. By adding default likelihood indicator into the Carhart [4] model, the empirical results demonstrate that a firm's credit situation change has significant negative effect on return of equity; lottery-type stocks equity returns are less sensitive to default risk going higher. Furthermore, this research also shows there exists a structure change resulted from the financial tsunami, indicating the investors require more positive excess returns to compensate their risk for holding stocks after 2008 financial crisis.
\end{abstract}

Keywords Lottery-type Stock, Credit Risk,
Idiosyncratic Risk

\section{Introduction}

"Risk Aversion" is a prevailing basic description of a person's attitude to return and risk in financial studies. However, it cannot be denied that there are also some investors having a preference for lottery-like assets, i.e., assets that have a relatively small probability of a large payoff. Golec \& Tamakin [5] shows that risk-adverse investors rationally sacrifice average return for the chance to win an extreme return. Downs \& Wen [6] find that extreme stock returns are associated with low-priced stocks, which in turn are correlated with a significant decline in average returns. They infer that investors in low-priced stocks accept lower (even negative) average returns as the premium paid for the chance to earn an extreme return, and depict this sacrifice in average return to be "lottery premium." Their analysis shows that the lottery premium is higher in up markets than in down markets.

Kumar [1] provides the characteristics of "lottery": first, lottery tickets have very low prices relative to the highest potential payoff; second, lotteries have low negative expected returns; and furthermore, lottery payoffs are very risky (the prize distribution has extremely high variance). Lotteries have an extremely small probability of a huge reward; this implies lotteries have positively skewed payoffs. Kumar [1] uses a unique data from a major U.S. brokerage house; the data set contains all trades and end-of-month portfolio positions. His empirical results show that individual investors' demand for lottery-type stocks increases when economic conditions worsen. At the aggregate level, individual investors prefer stocks with lottery features, and like lottery demand, the demand for lottery-type stocks increases during economic downturns. Because lottery-type stocks underperform, gambling- related underperformance is greater among low-income investors who excessively overweight lottery-type stocks.

Barberis \& Huang [7] derive a model under the cumulative prospect theory. In contrast to the prediction of a standard expected utility model, their model depicts a security with positive skewness can be "overpriced" and can earn a negative average excess return. Bali et al. [8] investigate the significance of extreme positive returns in the cross-sectional pricing of stocks. They find a negative and significant relation between the maximum daily return over the past one month and expected stock returns. Chen, et al. [9] examine the lottery premium phenomenon in Taiwan. The premium is higher in the recent past than in the remote past, and the lottery premium differs between the up and down markets.

Ang et al. [10] examine the pricing of aggregate volatility risk in the cross-section of stock returns. They find stocks with high sensitivities to innovations in aggregate volatility have low average returns; stocks with high idiosyncratic volatility relative to the Fama and French [11] model have low average returns. This phenomenon cannot be explained by exposure to aggregate volatility risk. Size, book-to-market, momentum, and liquidity effects cannot account for either the low average returns earned by stocks 
with high exposure to systematic volatility risk or for the low average returns of stocks with high idiosyncratic volatility. On the other hand, Ang, et al. [12] find that stocks with recent past high idiosyncratic volatility have low future average returns around the world. They use the data across 23 developed markets, the difference in average returns between the extreme quintile portfolios sorted on idiosyncratic volatility is $-1.31 \%$ per month, after controlling for world market, size, and value factors.

Although the extant literatures examine some issue related to the lottery-type stocks, most of the articles focus on underperform of it and do not discuss the relations between credit risk and lottery-type stocks. Credit risk is an issue which attracts more attentions from academic studies recently. It is worth noting that how the lottery-type stocks' characters are related to its credit risk. However, there are rare papers to explore about this topic. To fill the gap, the purpose of this study is to investigate the effect of credit risk on the lottery-type stocks.

This study explores the effect of credit risk on the lottery-type stocks with Taiwan's data. Taiwan has one of the most active stock markets in Asia, and over than $50 \%$ of the trading volume in the market is traded by individual investors. According to the study of Barber et al.[13], Taiwan's individual investor suffers an annual performance penalty of $3.8 \%$ points, equivalent to $2.2 \%$ of Taiwan's gross domestic product; comparing to the United States, the trading losses of individuals in US are about $2 \%$ points a year (Barber and Odean [14]). Barber et al.[13] conclude that higher individual trading losses in Taiwan are resulted from aggressive orders. Wang et al.'s[15] empirical evidence of options study in Taiwan market shows that those person who has less investing experience would prefer to invest lottery-type options. As the macro-economy condition becomes worse, instead, the lottery-type options investments will increase. Their findings are consistent with Kumar [1] that overconfidence is one of the major factors determine the investments in lottery-type assets.

The empirical results of this paper demonstrate that the lottery-type stocks have higher default probabilities, smaller firm sizes and higher $\mathrm{B} / \mathrm{M}$ ratio. To sort by $\mathrm{B} / \mathrm{M}$ ratio into quintile, it shows higher BM-ratio stocks have lower default risk. Furthermore, by adding default likelihood indicator into the Carhart [4] four-factor model, the results show that a firm's DLI likelihood change $\Delta(\mathrm{DLI})$, has significant negative effect on its return of equity. At the lowest DLI quintile, the four-factor model intercept $(\alpha)$ is significant positive, because the default factor is less important under very low DLI. However, as the default probabilities rising, the intercept $(\alpha)$ becomes negative, especially when the stock is non lottery-type. Lottery-type stocks equity returns are less sensitive to default risk going higher, because investors hold the lottery-type stocks will not care the credit risk influence as the same degree as they hold non-lottery type stocks. Furthermore, since worldwide financial tsunami also made extremely impact on Taiwan stock market, this study divides the total sample into two sub-periods, before (2001-2007) and after (2008-2010) the financial crisis; the findings show that there exists a structure change resulted from the financial tsunami, representing the investors require more positive excess returns to compensate their risks for holding all categories of stocks.

The remainder parts of this paper are: Section II describes the data and methodology of this research, the detail of multivariate regression models and the data sources. Section III demonstrates the summary statistics and empirical results of the article. Finally, section IV provides conclusions.

\section{Data \& Methodology}

This section introduces the proxies of lottery-type stocks, credit risk indicator and other variables respectively, the regression models of this study, and the data used.

\subsection{Method of Classification of Lottery-type Stocks}

Kumar [1] identifies the lowest $k t h$ stock price percentile, the highest $k t h$ idiosyncratic volatility percentile, and the highest $k t h$ idiosyncratic skewness percentile is likely to be perceived as lottery-type stocks. All three sorts are carried out independently. $k=50$. That is, the criteria are set at half. This study refers to Kumar (2009), at every month-end time point $t$, this study sort all the listing companies data by:

(1)The market price at the end of month $t-1$.

(2)The idiosyncratic volatility and the idiosyncratic skewness are measured by using the previous 6 months (i.e., months $t-6$ to $t-1)$ of daily returns data. Idiosyncratic volatility can be calculated as the variance of the residual $\varepsilon_{i, t}$ by fitting a four-factor model (Carhart, 1997) to the daily stock returns.

$$
\begin{array}{r}
R_{i, t}-r_{f, t}= \\
\alpha_{i}+\beta_{1 i}\left(R_{m, t}-r_{f, t}\right)+\beta_{2 i} S M B_{t}+\beta_{3 i} H M L_{t}+ \\
\beta_{4 i} U M D_{t}+\varepsilon_{i, t}
\end{array}
$$

$R_{i, t}$ is a firm's equity return, $r_{f, t}$ is risk free interest rate, $R_{m, t}$ represents the value-weighted market return. $R_{i, t}-r_{f, t}$ and $R_{m, t}-r_{f, t}$ indicate excess returns of a firm's equity and market portfolio respectively. $S M B_{t}$ is size factor, $H M L_{t}$ is book-to-market ratio factor, and $U M D_{t}$ is momentum factor. The calculation processes of these factors are explained in footnote $^{1}$.

1 The stocks are ranked by their size value and book-to-market ratio on month-end of June of year $t$. By the methods of Fama and French [11], Carhart [4], the two rankings are divided into to two equal groups by size (Big and Small) and three equal groups by book-to-market (High, Neutral and Low) respectively. $S M B_{t}$ is the equally weighted average returns of the small size portfolios minus the big size portfolios; $H M L_{t}$ is the equally weighted average returns of the low book-to- market ratio portfolios minus the high book-to- market ratio portfolios. To derive the momentum factor, the stock performance between months $t-12$ to $t-2$ are calculated, then ranked on June by the performance and divided into three subsamples: the top $30 \%$ (winners), the middle $40 \%$ (neutrals) and the bottom $30 \%$ (losers). $U M D_{t}$ is the equally weighted average returns of the winner portfolios minus the loser portfolios. The detail processes can be referred to Fama and French [11], Carhart [4], Lam and Li [19]. 
(3) To measure idiosyncratic skewness, refer to Kumar [1], Harvey and Siddique [16], Bali et al. [8], by estimating the following regression for each stock:

$$
R_{i, t}-r_{f, t}=\alpha_{i}+\beta_{i}\left(R_{m, t}-r_{f, t}\right)+\gamma_{i}\left(R_{m, t}-r_{f, t}\right)^{2}+\varepsilon_{i, t}
$$

The idiosyncratic skewness is defined as the skewness of daily residuals $\varepsilon_{i, t}$ of Eq. (2).

As mentioned above, at a time point, a stock in the following group is concurrently classified as a lottery-type stock: (i) the lowest 50th price percentile, (ii) the highest 50th idiosyncratic volatility percentile, and (iii) the highest 50th idiosyncratic skewness percentile. On the other hand, if a stock in the following groups concurrently at a specific time point is classified as a non-lottery type stock: (i) the highest 50th price percentile, (ii) the lowest 50th idiosyncratic volatility percentile, and (iii) the lowest 50th idiosyncratic skewness percentile. The remainder sample is categorized as "others" group.

\subsection{Data}

This study uses the dataset including all the stocks listed on the Taiwan Securities Exchange and the GraTai Securities Market, which are the two major stock markets in Taiwan. Refer to Bali et al. [8], financial and non-financial firms are totally included. The sample period covers from January 2001 through December 2010.I calculate the daily stock returns for each firm at each monthly end as well as such variables as the idiosyncratic volatility, various skewness measures, and other variables; all the data needed comes from the Taiwan Economic Journal (TEJ), a major data provider company in Taiwan.

\subsection{Method of Measuring Credit Risks}

This study employs DLI (Default likelihood index), which refers to Merton [2], Vassalou and Xing [3], and KMV (Moody's) method to be the proxy to measure credit risk. Merton [2] starts the research of structural form credit model. In Merton [2] model, the equity of a firm is viewed as a call option on the firm's assets. This study estimates the asset market value and volatility of a firm by employing an option-based method developed by Black and Scholes [17] and Merton [2], similar to the KMV (Moody's) credit evaluating methodology (Crosbie and Bohn [18]).

$$
\begin{gathered}
d V_{t}=\mu_{V} V_{t} d t+\sigma_{V} V_{t} d W_{V} \\
d S_{t}=\mu_{S} S_{t} d t+\sigma_{S} S_{t} d W_{S} \\
S_{t}=V_{t} N\left(d_{1}\right)-e^{-r(T-t)} D_{t} N\left(d_{2}\right) \\
d_{1}=\frac{\ln \left(V_{t} / S_{t}\right)+\left(r+\sigma_{v}^{2} / 2\right)(T-t)}{\sigma_{v} \sqrt{T-t}} \\
d_{2}=d_{1}-\sigma_{V} \sqrt{T-t} \\
\sigma_{V}=\sigma_{S}\left(V_{t} / S_{t}\right) N\left(d_{1}\right)
\end{gathered}
$$

A firm's asset value is denoted as $V_{t}, S_{t}$ represents its stock price, $V_{t}$ and $S_{t}$ follow log-normal stochastic processes. $\sigma_{V}, \sigma_{S}$ indicate the standard deviation of asset value and stock price respectively, $T-t$ is the remaining time to maturity of a firm's liabilities $D_{t}, \mu$ denotes the rate of growth of asset value. $r$ denotes the risk-free interest rate. Refer to Vassalou and Xing [3], this study employ short-term liabilities plus a half of long-term liabilities to be the default threshold proxy $D_{t}$. Calculate the volatility of equity returns as the standard deviation of daily equity return over the previous 150 trading days. The evaluation time point is the year-end date of the sample period. Then, $V_{t}$ and $\sigma_{V}$ can be solved from Eq.(5) and (8). The degree of credit risk of a corporate can be measured as Distance to Default (DD), or Probability of default (Pdef):

$$
\begin{gathered}
D D=\frac{\ln \left(V_{t} / D_{t}\right)+\left(\mu-\sigma_{v}^{2} / 2\right)(T-t)}{\sigma_{v} \sqrt{T-t}} \\
P_{\text {def }}=N(-D D)=N\left(-\frac{\ln \left(V_{t} / D_{t}\right)+\left(\mu-\sigma_{v}^{2} / 2\right)(T-t)}{\sigma_{v} \sqrt{T-t}}\right)
\end{gathered}
$$

$\mathrm{N}($.$) represents the cumulative normal distribution.$ Vassalou \& Xing [3] call the measure Pdef (Probability of default) as DLI (default likelihood indicators). This study uses the DLI as a proxy of a firm's credit risk.

\section{Empirical Results}

\subsection{Summary Statistics}

Table 1 shows the summary statistics for the variables of lottery type, non-lottery type and others group. The numbers in Table 1 are the mean values of each category with equally weighted. Sample number is the number of firm-month during the sample period. The results demonstrate the lottery-type firm-month sample share among 9.56\% in whole sample during the sample period.

$$
\frac{11680}{11680+11769+98725}=9.56 \%
$$

Non lottery-type also shares $9.63 \%$ in whole sample. The mean value of total volatility, idiosyncratic volatility, total skewness, systematic skewness, idiosyncratic skewness of the lottery-type sample is larger than the non-lottery type and the others categories. Idiosyncratic volatility is the variance of the residual obtained by fitting a four-factor model (Carhart [4]) to the daily stock returns. On the other hand, the average stock price of lottery-type stocks is the lowest among the three groups. The average firm size of lottery-type stocks is much smaller, and the non-lottery type firms have the largest average size. The B/M-ratio (book value of equity/market value of equity) shows that most lottery-type stocks have highest $\mathrm{B} / \mathrm{M}$ ratio because lottery-type stocks have lowest market price of stocks. This indicates that companies with lottery-type stocks have fewer growth opportunities. Furthermore, higher DLI indicates a firm with higher default probability; the lottery-type stocks also have highest DLI, and the non- lottery type group has the lowest 
default probabilities. Comparing to the non-lottery-type group, lottery-type stocks are illiquid (with higher Amihud [20] index) and smaller trading volume.

Table 1. Summary Statistics

\begin{tabular}{|c|c|c|c|}
\hline Measure & $\begin{array}{l}\text { Lottery } \\
\text { Type }\end{array}$ & $\begin{array}{c}\text { Non-Lottery } \\
\text { Type }\end{array}$ & Others \\
\hline $\begin{array}{l}\text { Sample Numbers } \\
\text { (firm-month) }\end{array}$ & 11680 & 11769 & 98725 \\
\hline Total Volatility (\%) & 3.1078 & 2.3844 & 2.8418 \\
\hline $\begin{array}{l}\text { Idiosyncratic } \\
\text { Volatility (\%) } \\
\end{array}$ & 2.5919 & 1.7699 & 2.3330 \\
\hline Total Skewness & 0.3870 & 0.1051 & 0.2980 \\
\hline Systematic Skewness & -4.2800 & -2.5132 & -3.9768 \\
\hline $\begin{array}{l}\text { Idiosyncratic } \\
\text { Skewness }\end{array}$ & 0.6338 & 0.1274 & 0.4849 \\
\hline Average Stock Price & 9.4404 & 36.1226 & 24.4156 \\
\hline Firm Size $\left(\times 10^{6}\right)$ & 2678 & 53815 & 16989 \\
\hline Book-to-Market Ratio & 1.3292 & 0.4343 & 1.1772 \\
\hline $\begin{array}{l}\text { Amihud Illiquidity } \\
\qquad\left(\times 10^{5}\right)\end{array}$ & 32.4248 & 13.6511 & 58.3195 \\
\hline $\begin{array}{l}\text { Monthly Volume } \\
\text { Turnover }\end{array}$ & 0.1505 & 0.1440 & 0.2301 \\
\hline Trading Volume & 49993 & 131277 & 21752 \\
\hline $\begin{array}{l}\text { Default Likelihood } \\
\text { Index (DLI) \% }\end{array}$ & 10.0758 & 6.2358 & 7.4636 \\
\hline
\end{tabular}

\subsection{B/M Effect Control on Default Risk}

Table 2 examines the relations of the $\mathrm{B} / \mathrm{M}$ effect and default risk by sorting the sample into quintile according to the firm's B/M ratio, and then check the average DLI of each quintile. The results show that in each group (lottery-type, non-lottery-type or others), higher B/M-ratio stocks (that is, value stocks) have lower DLI value (equivalent to lower default risk). This result is consistent with Vassalou \& Xing [3], which depict that value stocks have lower credit risk.

Table 2. B/M effect and default risk

\begin{tabular}{|c|c|c|c|c|c|}
\hline \multirow{2}{*}{ Groups } & \multicolumn{6}{|c|}{ Low B/M High B/M } \\
\cline { 2 - 6 } & 1 & 2 & 3 & 4 & 5 \\
\hline \multicolumn{5}{|c|}{ Average DLI } \\
\hline $\begin{array}{c}\text { Lottery-type } \\
\text { Lottery-type }\end{array}$ & 0.1220 & 0.1083 & 0.1124 & 0.0954 & 0.0668 \\
\hline Others & 0.0984 & 0.0861 & 0.0780 & 0.0727 & 0.0611 \\
\hline
\end{tabular}

For each quintile sorted by $\mathrm{B} / \mathrm{M}$ ratio, lottery-type stocks have higher DLI than others group and non- lottery type ones. This represents lottery-type stocks have higher default probabilities whether they have high $\mathrm{B} / \mathrm{M}$ or low $\mathrm{B} / \mathrm{M}$ ratios.

\subsection{Credit Risk Effect of Equity Return}

According to the empirical results of Vassalou \& Xing [3], default risk is systematic and Fama-French model contains a part of credit-relative information. Based on the above findings of Vassalou \& Xing [3], this study would like to examine whether credit risk change shall additionally influence the equity return. I executes the regression on the four-factor model (Carhart [4]) with monthly returns by adding an additional variable, $\Delta(\mathrm{DLI}) . \Delta(\mathrm{DLI})=\mathrm{DLI}_{\mathrm{t}}-$ $\mathrm{DLI}_{\mathrm{t}-1}$ which is the difference of a firm's DLI likelihood change to represent the credit risk condition changed.

$$
\begin{gathered}
R_{i, t}-r_{f, t}=\alpha_{i}+\beta_{1 i}\left(R_{m, t}-r_{f, t}\right)+\beta_{2 i} S M B_{t}+ \\
\beta_{3 i} H M L_{t}+\beta_{4 i} U M D_{t}+\beta_{5 i} \Delta(D L I)_{t}+\varepsilon_{i, t}
\end{gathered}
$$

The results show in Table 3, and the value in the parenthesis is t-value; *,**,*** represent $10 \%, 5 \%$ and $1 \%$ significance level respectively. The regression coefficient of $\Delta(\mathrm{DLI})$, whether in the lottery-type or non lottery-type sample, is significant negative. It represents that when the default risk rises $\left(\mathrm{DLI}_{\mathrm{t}}-\mathrm{DLI}_{\mathrm{t}-1}>0, \rightarrow \Delta(\mathrm{DLI})\right.$ rises), the return of equity will go down significantly. It indicates that credit risk condition change will additionally influence the equity return beside Carhart [4] four-factor model.

The intercept of the four-factor model, $\alpha$, represents the excess return, is significant negative in the cases of non lottery-type and others group. However, the intercept $\alpha$ is insignificant (slightly positive) in the lottery-type stocks. For further analysis, I sort the lottery-type and non lottery-type samples by DLI into quintile, and execute Carhart [4] four-factor model again, in order to observe the change of the intercept $(\alpha)$. The regression results will be analyzed in Table 4.

Table 4 shows the results of Carhart [4] four-factor model by sorting lottery and non- lottery type stocks into quintile by DLI.

$$
\begin{gathered}
R_{i, t}-r_{f, t}=\alpha_{i}+\beta_{1 i}\left(R_{m, t}-r_{f, t}\right)+\beta_{2 i} S M B_{t}+ \\
\beta_{3 i} H M L_{t}+\beta_{4 i} U M D_{t}+\varepsilon_{i, t}
\end{gathered}
$$

At the lowest DLI quintile (low credit risk), whether lottery-type or non-lottery type, both have the significant positive intercept $(\alpha)$, it indicates that stocks with lower default risk enjoy higher excess returns. However, as the default probabilities rising (higher DLI), $\alpha$ becomes negative, especially the non-lottery type stocks are significantly negative. The reason why default risk influences heavily on non-lottery-type stocks when credit risk goes high, may be explained as follows: because lottery-type stocks are much higher risky (with higher idiosyncratic volatility and higher skewness) than the non-lottery type ones, investors hold the lottery-type stocks will not care the credit risk influence as the same degree as they hold non-lottery type stocks. Therefore, lottery-type stocks equity returns are less sensitive to default risk going higher. 
Table 3. Credit risk effect of equity return.

\begin{tabular}{|c|c|c|c|c|c|c|}
\hline Groups & $\alpha$ & $\left(R_{m, t}-r_{f, t}\right)$ & SMB & HML & UMD & $\Delta(\mathrm{DLI})$ \\
\hline \multirow{2}{*}{ Lottery type } & 0.0117 & 0.01537 & 0.4325 & 0.7896 & -0.1382 & -0.7518 \\
& $(0.3230)$ & $(0.3352)$ & $(5.6961)^{* * *}$ & $(11.8713)^{* * *}$ & $(-2.3972)^{* * *}$ & $(-3.2219)^{* * *}$ \\
\hline Non-Lottery & -0.2010 & 0.0457 & 0.4550 & 0.2045 & -0.1537 & -1.6787 \\
Type & $(-7.99)^{* * *}$ & $(1.4851)$ & $(8.8233)^{* * *}$ & $(4.8179)^{* * *}$ & $(-4.0528)^{* * *}$ & $(-7.6998)^{* * *}$ \\
\hline \multirow{2}{*}{ Others } & -0.0523 & 0.1197 & 0.4494 & -0.3867 & -0.0485 & -0.8108 \\
& $(-3.4271)^{* * *}$ & $(6.4617)^{* * *}$ & $(14.5452)^{* * *}$ & $(15.6782)^{* * *}$ & $(-2.1488)^{* * *}$ & $(-7.8173)^{* * *}$ \\
\hline
\end{tabular}

Table 4. Regressions for $\alpha$ by control on credit risk

\begin{tabular}{|c|c|c|c|c|c|}
\hline & \multicolumn{3}{|c|}{ Low DLI (Low Credit Risk) } & \multicolumn{2}{|c|}{ High DLI (High Credit Risk) } \\
\hline & 1 & 2 & 3 & 4 & 5 \\
\hline & \multicolumn{5}{|c|}{ Four factor $\alpha$} \\
\hline Lottery type & $\begin{array}{c}0.2312 \\
(2.7873)^{* * *}\end{array}$ & $\begin{array}{r}-0.0920 \\
(-1.0156) \\
\end{array}$ & $\begin{array}{c}0.0151 \\
(0.1939) \\
\end{array}$ & $\begin{array}{r}-0.0290 \\
(-0.3831) \\
\end{array}$ & $\begin{array}{c}0.0563 \\
(0.5490) \\
\end{array}$ \\
\hline $\begin{array}{l}\text { Non-Lottery } \\
\text { Type }\end{array}$ & $\begin{array}{c}0.1950 \\
(3.3619)^{* * *}\end{array}$ & $\begin{array}{c}-0.1868 \\
(-3.2484)^{* * *}\end{array}$ & $\begin{array}{c}-0.2907 \\
(-4.8946) * * *\end{array}$ & $\begin{array}{c}-0.4909 \\
(-8.5074)^{* * *}\end{array}$ & $\begin{array}{c}-0.1661 \\
(-2.4552)^{* * * *}\end{array}$ \\
\hline
\end{tabular}

\subsection{The Effect of 2008 Financial Tsunami}

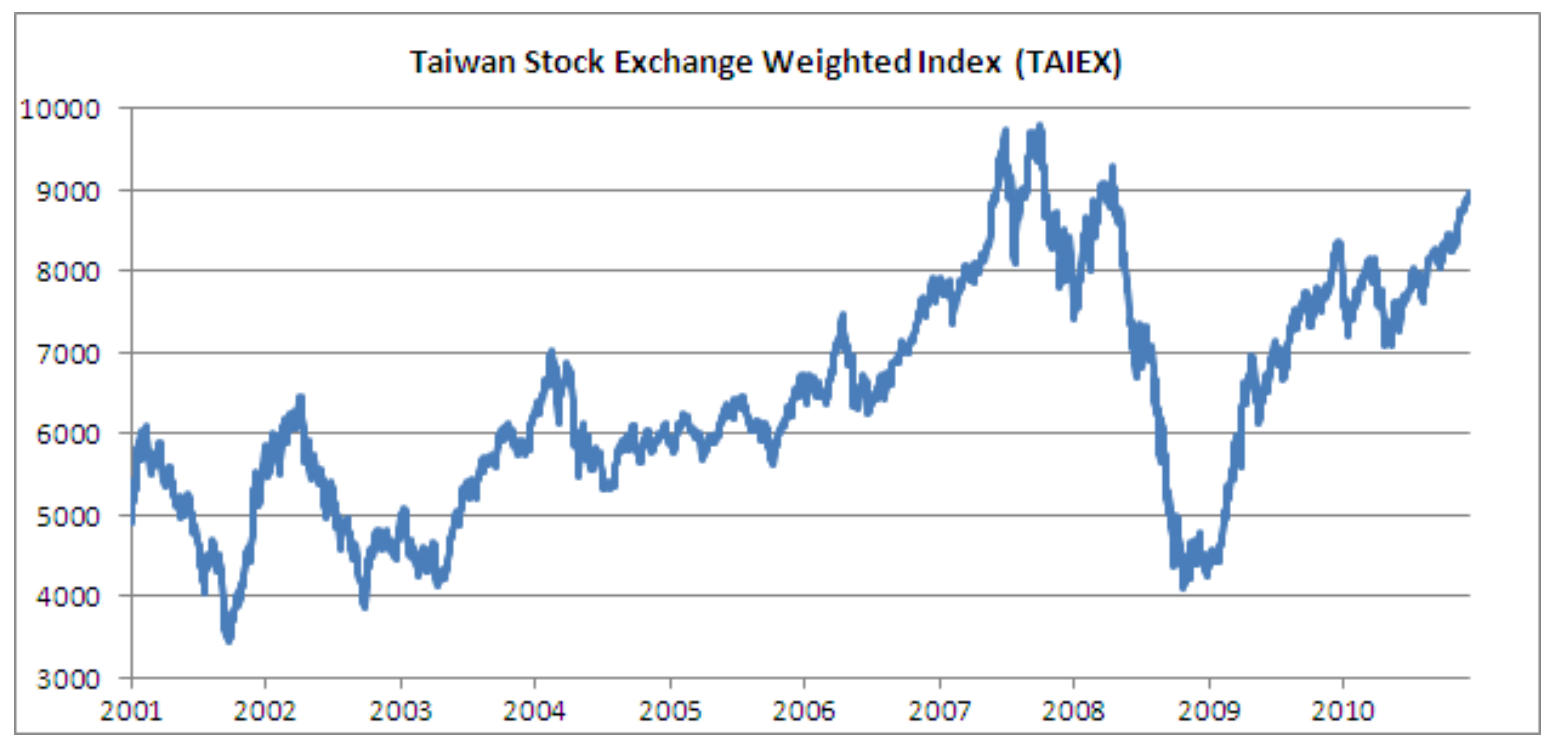

Figure 1. The trend of TAIEX index during the sample period 2001-2010

Table 5. Credit risk effect of equity return of the two sub-periods before and after financial tsunami

\begin{tabular}{|c|c|c|c|c|c|c|c|}
\hline Groups & Sub-period & $\alpha$ & $\left(R_{m, t}-r_{f, t}\right)$ & SMB & HML & UMD & $\Delta(\mathrm{DLI})$ \\
\hline \multirow{2}{*}{ Lottery type } & Before & $\begin{array}{c}0.0003 \\
(0.0063)\end{array}$ & $\begin{array}{c}0.2848 \\
(4.5018)^{* * *}\end{array}$ & $\begin{array}{c}0.5523 \\
(5.6405)^{* * *}\end{array}$ & $\begin{array}{c}0.8896 \\
(12.2423)^{* * *}\end{array}$ & $\begin{array}{c}0.2120 \\
(2.9197)^{* * *}\end{array}$ & $\begin{array}{c}-0.4752 \\
(-1.3960)\end{array}$ \\
\hline & After & $\begin{array}{c}0.2442 \\
(3.1117)^{* * *} \\
\end{array}$ & $\begin{array}{c}-0.2748 \\
(-2.7366)^{* * *}\end{array}$ & $\begin{array}{c}0.8446 \\
(6.3943)^{* * *} \\
\end{array}$ & $\begin{array}{c}0.1048 \\
(0.3638) \\
\end{array}$ & $\begin{array}{c}-0.8673 \\
(-7.9627)^{* * *}\end{array}$ & $\begin{array}{c}-0.4910 \\
(-1.5857) \\
\end{array}$ \\
\hline \multirow{2}{*}{$\begin{array}{l}\text { Non-Lottery } \\
\text { Type }\end{array}$} & Before & $\begin{array}{c}-0.3120 \\
(-9.7534)^{* * *}\end{array}$ & $\begin{array}{c}0.0784 \\
(1.9010)^{*}\end{array}$ & $\begin{array}{c}0.6416 \\
(9.8225)^{* * *}\end{array}$ & $\begin{array}{c}0.2661 \\
(6.0256)^{* * *}\end{array}$ & $\begin{array}{c}0.1209 \\
(2.5695)^{* *}\end{array}$ & $\begin{array}{c}-1.9715 \\
(-5.9483)^{* * *}\end{array}$ \\
\hline & After & $\begin{array}{c}0.1301 \\
(2.3861)^{* *} \\
\end{array}$ & $\begin{array}{c}-0.0833 \\
(-1.2006) \\
\end{array}$ & $\begin{array}{c}0.5020 \\
(5.5478)^{* * *} \\
\end{array}$ & $\begin{array}{c}-0.0921 \\
(-0.4607) \\
\end{array}$ & $\begin{array}{c}-0.9645 \\
(-12.8728)^{* * *} \\
\end{array}$ & $\begin{array}{c}-0.6079 \\
(-2.2001)^{* *} \\
\end{array}$ \\
\hline \multirow{2}{*}{ Others } & Before & $\begin{array}{c}-0.1507 \\
(-7.8632)^{* * *} \\
\end{array}$ & $\begin{array}{c}0.3064 \\
(12.5167)^{* * *} \\
\end{array}$ & $\begin{array}{c}0.6610 \\
(17.4226)^{* * *} \\
\end{array}$ & $\begin{array}{c}0.5134 \\
(19.4249)^{* * *}\end{array}$ & $\begin{array}{c}0.2749 \\
(9.9227)^{* * *} \\
\end{array}$ & $\begin{array}{c}-0.6678 \\
(-4.6083)^{* * * *} \\
\end{array}$ \\
\hline & After & $\begin{array}{c}0.4002 \\
(10.9038)^{* * *}\end{array}$ & $\begin{array}{c}-0.1630 \\
(-3.2970)^{* * *}\end{array}$ & $\begin{array}{c}0.7512 \\
(12.2078)^{* * *}\end{array}$ & $\begin{array}{c}-0.3010 \\
(-2.1753)^{* *}\end{array}$ & $\begin{array}{c}-1.0691 \\
(-20.3695)^{* * *}\end{array}$ & $\begin{array}{c}-0.2761 \\
(-1.9194)^{*}\end{array}$ \\
\hline
\end{tabular}


Figure 1 shows the trend of Taiwan stock exchange weighted index (TAIEX) during the sample period 2001-2010. Since the sample period lies across the 2008 worldwide financial tsunami, Taiwan stock market is also influenced by the event. The index declined sharply in 2008, and bounce back fast in 2009. For analyzing the difference before and after the financial tsunami, this study divides the total sample period into two sub-periods, before (2001-2007) and after (2008-2010) the financial crisis.

Eq.(11) is executed with the sub-periods sample and the results are demonstrated in Table 5. It shows the regression coefficient of $\Delta(\mathrm{DLI})$, is no longer significant in the lottery-type stocks, but are still negative significant in non lottery-type and others groups. The results represent the default risk effect would not give significant impact on lottery-type stock in sub-sample periods; indicating that investors who invest on lottery-type stocks would not put their attentions on credit risk change; lottery-type stocks equity returns are less sensitive to default risk going higher, whether before or after 2008 financial crisis. Furthermore, the intercepts of the four-factor model, $\alpha$, are initially negative significant (non lottery-type and others group) or insignificant (lottery-type) before tsunami, however, all turn to be positive significant after 2008. This phenomenon represents there exists a structure change resulted from the financial tsunami, which indicates that the investors require positive excess returns to compensate their risks, whether they hold any category stocks.

\section{Conclusions}

This study explores the effect of credit risk on the lottery-type stocks with Taiwan's data. By empirical study, the conclusions show that the lottery-type stocks have higher default probabilities (with higher DLI), smaller firm sizes and higher $\mathrm{B} / \mathrm{M}$ ratio, lower liquid and smaller trading volume comparative to the non lottery-type ones. To sort by $\mathrm{B} / \mathrm{M}$ ratio into quintile, it demonstrates higher $\mathrm{B} / \mathrm{M}$ ratio stocks have lower default likelihood, which is consistent with Vassalou \& Xing [3] that value stocks have lower credit risk.

Based on the empirical results of Vassalou \& Xing [3] that default risk is systematic, this study examines the credit risk change shall additionally influence the equity return; by adding the default likelihood indicator into the Carhart [4] four-factor model, it shows that a firm's DLI likelihood change the coefficient of $\Delta(\mathrm{DLI})$, has significant negative effect on its return of equity, which represents the credit risk condition will additionally influence the equity return beside Carhart [4] four-factor model.

Furthermore, this study also find that default risk influences heavily on non-lottery type stocks equity returns than lottery-type ones when credit risk goes high, because investors hold the lottery-type stocks will not care the credit risk influence as the same degree as they hold non-lottery type stocks, so that, lottery-type stocks equity returns are less sensitive to higher default risk. Besides, with the results of sub-periods before and after 2008 financial tsunami, this study shows that there exists a structure change resulted from the financial crisis, which indicates the investors require more positive excess returns to compensate their risks for holding stocks.

\section{REFERENCES}

[1] Kumar, A., 2009, "Who gambles in the stock market?" , Journal of Finance 64, pp. 1889-1933.

[2] Merton, R.C., 1974, "On the pricing of corporate debt: the risk structure of interest rates." Journal of Finance 29, pp. 449-470.

[3] Vassalou, M. and Y. Xing, 2004, "Default risk in equity returns.” Journal of Finance 59, pp. 831-868.

[4] Carhart, M. M., 1997, "On persistence in mutual fund performance”, Journal of Finance 52, pp. 57-82.

[5] Golec, J., and M. Tamarkin, 1998, "Bettors love skewness, not risk at the horse track," Journal of Political Economy, 106, pp. 205-225.

[6] Downs, T. W. and Q. Wen, 2001, "Is there a lottery premium in the stock market?", Journal of Portfolio Management 28, pp. 112-119.

[7] Barberis N. and M. Huang, 2008, "Stocks as lotteries: the implications of probability weighting for security prices", American Economic Review 98:5, pp. 2066-2100.

[8] Bali T. G., N. Cakici, and R. F. Whitelaw, 2011, "Maxing out: Stocks as lotteries and the cross-section of expected returns", Journal of Financial Economics 99, pp. 427-446.

[9] Chen, M. H., S. J. Chen, M. F. Yen, and Y. C. Shen, 2008. "Lottery premium in the Taiwan stock market", Asia Pacific Management Review 13, pp. 545-556.

[10] Ang, A., R. J. Hodrick, Y. Xing, and X. Zhang, 2006, "The cross-section of volatility and expected returns", Journal of Finance 61, pp. 259-299.

[11] Fama, E. F. and K. R. French, 1993, "Common risk factors in the returns on stocks and bonds", Journal of Financial Economics 33, pp. 3-56.

[12] Ang, A., R. J. Hodrick, Y. Xing, and X. Zhang, 2009, "High idiosyncratic volatility and low returns: international and further U.S. evidence", Journal of Financial Economics 91, pp. 1-23.

[13] Barber, B. M., Y. T. Lee., Y. J. Liu. and T. Odean, 2009, "Just how much do individual investors lose by trading?" Review of Financial Studies 22, pp. 609-632.

[14] Barber, B., and T. Odean, 2000, "Trading Is Hazardous to Your Wealth: The Common Stock Investment Performance of Individual Investors", Journal of Finance 55, pp. 773-806.

[15] Wang, M.-C., Y.-L. Chen, C.-Y. Wu and W.-L. Lin, 2014, "Who gambles in the option market?", Taiwan Journal of Applied Economics 96, pp. 191-228. (in Chinese) 
[16] Harvey, C. R. and A. Siddique, 2000, "Conditional skewness in asset pricing tests", Journal of Finance 55, pp. 1263-1295.

[17] Black, F. and M. Scholes, 1973, "The pricing of options and corporate liabilities". Journal of Political Economy 81, pp. 637-654.

[18] Crosbie, P. J and J. R. Bohn, 2003. "Modeling default risk", Moody's KMV.
[19] Lam, K. S. K. and F. K. Li, 2008, "The risk premiums of the four-factor asset pricing model in the Hong Kong stock market”, Applied Financial Economics 18, pp. 1667-1680.

[20] Amihud, Y., 2002, "Illiquidity and stock returns cross-section and time-series effects", Journal of Financial Markets 5, pp. $31-56$. 